\title{
Soil moisture stress mitigation for sustainable upland rice production in the Northern Guinea Savanna of Nigeria
}

\author{
${ }^{*}$ Odunze $^{1}$ A.C, Kudi T. M, Daudu ${ }^{2}$ C, Adeosun ${ }^{2}$ J, Ayoola ${ }^{5}$ G, Amapu ${ }^{1}$ I.Y, Abu ${ }^{1}$ S. T, \\ Mando ${ }^{3} . A, E^{2} i^{3}$. G and Constance ${ }^{3}$. D \\ ${ }^{1}$ Department of Soil Science/IAR, Ahmadu Bello University, Zaria \\ ${ }^{2}$ National Agriculture and Extension Liaison services, Ahmadu Bello University, Zaria \\ University of Agriculture, Maiduguri \\ ${ }^{3}$ International Fertilizer Development Corporation Lome \\ ${ }^{4}$ Department of Agricultural Economics and Rural Sociology, Ahmadu Bello \\ University, Zaria \\ ${ }^{5}$ University of Agriculture, Makurdi, Nigeria
}

\begin{abstract}
Northern Guinea Savanna (NGS) of Nigeria cultivable lands have sandy loam to loamy sand surface textures, low organic matter and are susceptible to erosion (wind and water). To mitigate crop moisture stress, on-farm trials involving contour-ridge-tying and contour ridging were carried out in Albasur and Dansoda villages in Dandume Local Government Area of Katsina State (NGS) to conserve soil against erosion and moisture for crop use in 2008 and 2009. The area (NGS) witness poor rainfall distribution, dry spells lasting beyond twenty one days occurring between June and July and low rainfall amounts ( $<900$ to $1300 \mathrm{~mm}$ per annum). These result in upland crops like rice (NERICA 2 var.) witnessing deficit soil moisture to undergo proper growth and production, low yields or complete crop failure. Also, soil erosion and runoff deplete water that could be available for crops and degrade farmlands for continued cultivation on the land. In this trial farmers ranked their rice grain yields while physical and agronomic data collected were statistically analysed using ANOVA and Duncan multiple range tests to separate means. Results show that cross-banded ridge resulted in significantly higher rice grain yields than the other treatments and was followed by contoured ridge. Socio-economic data collected were analyzed using descriptive statistics and budgeting technique. Costs and returns analysis results show that labour and fertilizer inputs accounted for greater proportion of total variable costs incurred in contour $(15.72 \%)$, contour plus tie ridging (15.72\%), planting on flat land and farmers ridging practice (16.43 and $16.55 \%$ respectively). Costs and returns analysis result shows that rice cultivation using contour and contour plus tie ridging is more profitable, implying feasible sustainable rice production through contour farming.
\end{abstract}

Keywords: Rice Production, Soil and Water conservation, Moisture Stress Mitigation, Promotion, Dissemination, Contour Farming, Costs, Returns

\section{INTRODUCTION}

The Northern Guinea Savanna (NGS) of Nigeria commonly witness poor rainfall distribution, dry spells, surface wash and runoff on farms (Kowal and Knabe, 1972), and result in soil moisture deficiency that depress crop yield or complete crop failure at the uplands. Also, the upland soils have very low moisture retention capacity, poor inherent fertility status and are dominated with low activity clays; in particular kaolinitic clays (Jones and Wild, 1975; Lombin, 1987; Odunze et al., 1996; Odunze, 2006). Crops grown at the uplands in the zone include maize, sorghum, upland rice, cowpea, groundnut and soybeans. Strategies to ensure soil and water conservation for sustainable crop production was sought and moisture stress mitigation using contoured ridges, contoured ridges+ cross-banding, ridging up-down slope direction and planting on flat harrowed plots was evaluated in this study. Soil moisture stress mitigation trials were undertaken in two villages (Albasur and Dansoda) in Dandume Local Government Areas (LGA) of Katsina State in Nigeria (North $11^{\circ} 24$, East $7^{\circ} 07.5^{\prime}$ and Alt. 687m) in the Northern Guinea Savanna of Nigeria (NGS) from 2008 to 2009. The area (NGS) witness poor 
rainfall distribution pattern and has rainfall amounts ranging between $<900$ to a maximum of $1300 \mathrm{~mm}$ per annum (p.a). The implication of this is that field crops often witness dry spells and/ or insufficient soil moisture to undergo proper growth and production processes, resulting in low yields or complete crop failure. Surface wash and runoff further compounds the poor soil quality of the NGS of Nigeria as erosion degrades the land, pollutes the soil, surface and underground water.

The study on moisture stress mitigation was therefore aimed at determining appropriate strategy (ies) that would best conserve soil and moisture on farmlands to result in optimal rice grain and stover yields and improve on farmers' livelihoods. Also the study aimed to create awareness and promote the adoption of improved land management practices for moisture stress mitigation and increase rice yield

\section{MATERIALS AND METHODS}

In a pre-trial survey of Katsina State conducted by International Fertilizer Development Centre (IFDC) to obtain baseline data, Dandume area was chosen as dominant upland rice producing LGA in Katsina State and upland rice (NERICA) variety was chosen and evaluated as a test crop. The trial treatments were

1. Up-Down slope Ridging practice [U-DR]

2. Contour Ridging [C]

3. Contour Ridging +tied ridges [CT] (CrossBanded Ridges)

\section{Planting on Flat and Harrowed plots [F]}

Also, Participatory Action Learning Research on Rice production with contours was organized for all the farmers in the village who identified with the trial to create awareness and assess the treatments for best practical option(s) for adoption. Farmer exchange visits to explain better soil moisture storage; hence improved crop performance was also conducted for farmers in the study location. Farmers were also taught ranking with stones and ranked their crop performance using their 2009 rice grain yields. Socio-economic data were collected through structured questionnaire and the data were analyzed using descriptive statistics and budgeting technique. Undisturbed core soil samples were also collected from the treatments at $0-5$ and $5-10 \mathrm{~cm}$ depths at three periods of dry spell, and the soil samples were analysed for bulk density and moisture content of soils under the treatments. Plot area was 20 by $10 \mathrm{~m}$ $=200 \mathrm{~m}^{2}$

\section{RESULTS AND DISCUSSION:}

Particle Size Distribution: Table 1 presents information on the particle size distribution of soils of farmers' fields in Albasur village. The data shows that the soils are dominated with sand separates with values ranging between 34 and $54 \%$ at the surface layers $(0-15 \mathrm{Cm})$ and 38 to $42 \%$ at the $15-30 \mathrm{~cm}$ depths, indicating a reduction in sand fraction with increase in depth. Silt fractions ranged between 28 and $34 \%$ at the $0-15 \mathrm{~cm}$ layers and 34 to $44 \%$ at the $15-30 \mathrm{~cm}$ depths. This suggests that silt fractions are high in the soil and increased with increase in depth. The high silt content of the soils would predispose the soils to crusting after rainfall and this could impair infiltration, gaseous exchange in soil, seed germination and encourage runoff and surface wash on the farms.

Table 1: Physical Properties of Soils of Dandume Study Area

\begin{tabular}{|l|l|l|l|l|l|}
\hline Location/Farm & Depth & $\begin{array}{l}\text { Sand } \\
\mathbf{2 - . 0 5} \mathbf{~ m m}\end{array}$ & $\begin{array}{l}\text { Silt } \\
\mathbf{. 5 - . 0 0 2} \\
\mathbf{m m}\end{array}$ & $\begin{array}{l}\text { Clay } \\
\mathbf{0 . 0 0 2} \\
\mathbf{m m}\end{array}$ & $\begin{array}{l}\text { Textural } \\
\text { Classification }\end{array}$ \\
\hline Albasur & Cm & \multicolumn{3}{|c|}{$---------\%---------$} & USDA \\
\hline Alh. MaiGari & $0-15$ & 54 & 30 & 16 & Sandy Loam \\
\hline & $15-30$ & 40 & 34 & 26 & Loam \\
\hline Alh. Muktari & $0-15$ & 34 & 34 & 32 & Clay Loam \\
\hline & $15-30$ & 38 & 44 & 18 & Loam \\
\hline Alh. Lawal & $0-15$ & 38 & 28 & 34 & Clay Loam \\
\hline & $15-30$ & 42 & 34 & 24 & Loam \\
\hline
\end{tabular}

Clay fractions of the soils were moderate to high at both depths evaluated. Values range from 16 to 34 $\%$ at the surface and 18 to $24 \%$ at the $15-30 \mathrm{Cm}$ depths. The high clay contents of the surface layers could detain/delay water infiltration to benefit paddy rice. However, it does appear that top soil layers in 
the study area had been eroded leaving sub-soil rich materials as the present surface soils. Generally soils of the zone are dominated with Alfisols (Odunze, 2006; Esu and Ojenuga, 1987) and the soils characteristically exhibit argillic subsoil properties. Texture of the soils therefore ranges between sandy loam and Clay loam to loam both at the surface and sub surface layers of crop rooting zone (Table 1).

\section{Physical Properties of the Soils}

Bulk Density and Moisture Content: Mean bulk density of soils under the treatments (Table 2) showed significant difference, between treatments, except between contoured ridge and Contour+Ridgetied treatments. The least bulk density was obtained under Up-Down slope $\left(1.51 \mathrm{Mgm}^{-3}\right)$. However, the highest bulk density obtained under the Flat planting treatment $\left(1.60 \mathrm{Mgm}^{-3}\right)$ is attributed to silt accumulation on the surface soil layer and formation of crust which hardened to increase surface soil bulk density (Ike, 1987; Ike, 1986). The significantly lower bulk density under Contour and Contour+ridge-tie treatments than the Flat planting treatment suggests that crusting and surface soil hardening is less prominent under the Contour and Contour+Ridgetied treatment (Table 2). Table 3 shows that bulk density decreased with depth in all the instances considered, with the surface layers having a significantly high bulk density value of $1.58 \mathrm{Mgm}^{-3}$ while the sub-surface depths had a bulk density of $1.51 \mathrm{Mgm}^{-3}$. Perhaps crusting by silt particles at the surface layers depth could account for the higher soil moisture in the surface layers. Increasing clay at depths will impair subsoil drainage and cause temporary sub soil water stagnation (Odunze et al., 2008; Dim et al. 2008). High bulk density values under Flat, contoured and Contour+Cross banded ridge treatments could be attributed to effect of crusting (Ike, 1987; Kowal and Knabe, 1972; Lombin, 1987) following delayed water movement/runoff, compared with up-down slope ridging (Flat planting is done on harrowed and non-ridged fields irrespective of the slope of the field) that could allow more rapid surface water movement/runoff on the farms. Also, between soil sampling dates (Table 4), bulk density did not show any statistical difference, suggesting that sampling date did not affect bulk density changes. This perhaps resulted from the fact that samples were obtained at periods of at least two weeks after the last rainfall in the village.

Soil moisture content between treatments (Table 2) did not significantly differ between treatments, though the Up-Down Slope treatment resulted in higher than all the other treatments and is followed by Contour+Ridge-tie treatments. Moisture content however increased with depth generally, perhaps moisture content increased with increasing clay content as clay would cause impaired drainage at the sub surface depths ((Odunze, 2003; Dim et al., 2008). Between dates of sampling however, moisture content did not significantly changed.

Table 2: Soil Bulk Density and Moisture Content of Rice Trial Sites in Dandume

\begin{tabular}{|l|l|l|}
\hline Treatments & $\begin{array}{l}\text { Bulk } \\
\text { Density }\end{array}$ & $\begin{array}{l}\text { Moisture } \\
\text { Content }\end{array}$ \\
\hline & $\mathrm{Mg} \mathrm{m}^{-3}$ & $\mathrm{Cm}^{3} \mathrm{Cm}^{-3}$ \\
\hline Contour & $1.53 \mathrm{ba}$ & $0.53 \mathrm{a}$ \\
\hline Contour+Ridge tie & $1.54 \mathrm{ba}$ & $0.59 \mathrm{a}$ \\
\hline $\begin{array}{l}\text { Up-Down slope } \\
\text { Ridging }\end{array}$ & $1.51 \mathrm{~b}$ & $0.63 \mathrm{a}$ \\
\hline Flat & $1.60 \mathrm{a}$ & $0.55 \mathrm{a}$ \\
\hline
\end{tabular}

Means with the same letters are not significantly different

Table 3: Soil Bulk Density and Moisture content with Depth

\begin{tabular}{|l|l|l|}
\hline Depth & $\begin{array}{l}\text { Bulk } \\
\text { Density }\end{array}$ & Moisture content \\
\hline $\mathrm{Cm}$ & $\mathrm{Mg} \mathrm{m}{ }^{-3}$ & $\mathrm{Cm}^{3} \mathrm{Cm}^{-3}$ \\
\hline $0-5$ & $1.58 \mathrm{a}$ & $0.44 \mathrm{~b}$ \\
\hline $5-10$ & $1.51 \mathrm{~b}$ & $0.72 \mathrm{a}$ \\
\hline
\end{tabular}

Means with the same letters are not significantly different

Table 4: Bulk Density and Soil Moisture Content Over time

\begin{tabular}{|l|l|l|}
\hline $\begin{array}{l}\text { Dates of } \\
\text { Sampling }\end{array}$ & Bulk Density & $\begin{array}{l}\text { Moisture } \\
\text { Content }\end{array}$ \\
\hline & $\mathrm{Mgm}^{-3}$ & $\mathrm{Cm}^{3} \mathrm{~cm}^{-3}$ \\
\hline $04-07-09$ & $1.55 \mathrm{a}$ & $0.57 \mathrm{a}$ \\
\hline $27-06-09$ & $1.53 \mathrm{a}$ & $0.61 \mathrm{a}$ \\
\hline $14-11-09$ & $1.55 \mathrm{a}$ & $0.55 \mathrm{a}$ \\
\hline
\end{tabular}

Rice Yield: Table 5 shows that significantly higher rice grain yield was obtained Contour+Cross banded ridge (1.68tha $\left.{ }^{-1}\right)$ and Contoured ridge (1.64 tha $\left.{ }^{-1}\right)$ than flat planting (1.36tha $\left.{ }^{-1}\right)$ and lastly Up-Down slope $\left(1.12\right.$ tha $\left.^{-1}\right)$ treatments for the 2008 and 2009 trial years. 
It is realizable that among the treatments, Contour+Cross banded ridges resulted in significantly highest grain yield than all the treatments over the two years the study was conducted. Also contoured ridge treatment resulted in significantly higher grain yield $\left(1.64\right.$ tha $\left.^{-1}\right)$ than Updown slope ridging and Flat planting.

Table 5: Rice Yield in Dandume 2008-2009

\begin{tabular}{|l|l|l|l|}
\hline Treatment & $\begin{array}{l}\text { Grain } \\
\text { (tha }^{-1} \text { ) }\end{array}$ & $\begin{array}{l}\text { \% } \\
\text { Difference }\end{array}$ & $\begin{array}{l}\text { Stover } \\
\text { (tha }^{-1} \text { ) }\end{array}$ \\
\hline Contour & $1.635 \mathrm{a}$ & 46.24 & $2.363 \mathrm{a}$ \\
\hline $\begin{array}{l}\text { Contour } \\
\text { +Ridge tie }\end{array}$ & $1.678 \mathrm{a}$ & 50.09 & $2.392 \mathrm{a}$ \\
\hline $\begin{array}{l}\text { Up-Down } \\
\text { Slope }\end{array}$ & $1.118 \mathrm{~b}$ & - & $2.072 \mathrm{a}$ \\
\hline Flat & $1.355 \mathrm{ba}$ & 21.20 & $2.013 \mathrm{a}$ \\
\hline
\end{tabular}

Means with the same letters are not significantly different

The result would therefore suggest that Contoured+Cross banded ridges would result in $\mathbf{5 0}$ $\%$ higher grain yield than Up-Down slope ridging. Contoured ridging gave $46 \%$ grain yield higher than Up-Down slope ridging. Commonly in the NGS of Nigeria, farmers plant upland rice on the flats after harrowing the fields. A few farmers however plant on ridges made without considering slope direction, but commonly prefer up-down slope for ease of ridging operation. In the context of farmers' practice therefore, Flat planting and Up-Down slope planting had not supported sustainable rice grain yield but part-contributed to reduced rice yield, soil degradation and increased farmer poverty conditions. The least grain yield under Up-Down slope ridging is attributed to effects of runoff, moisture depletion, nutrients depletion due to surface wash and eroded/degraded state of the soils. Adoption of contouring with cross banding of ridges on farmers' fields is potentially capable of assuring optimal upland rice grain yield, alleviating farmer poverty/livelihoods with environmental protection and sustainable soil maintenance.

Data on stover yields of rice (Table 5) under either of the treatments were not significantly different, but suggests that NERICA upland rice would yield a little over 2 tha $^{-1}$ of stover that could be used for feeding livestock or ploughed into the soil to improve the soil carbon contents, moisture retention capacity of the soils, check nutrients loss to leaching and soil erosion.

Cost and Returns Analysis: The costs and returns analysis (Table 6) indicate that labour and fertilizer inputs account for greater parts of total variable costs incurred in all the treatments. Gross margin analysis of contour farming practices (Table 6) show that from one hectare of cultivated land, total cost of production for contour, contour+ridge-tie, flat planting and farmer's practice (up-down slope) in Albasur

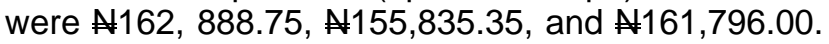
Also gross revenue of $\$ 243,250.00$ was obtained for contour and contour+ridge-tie, $\$ 163,800.00$ and A133,350.00/ha for planting on flat land and farmers practice respectively; thus giving a gross margin of A80,361.25 for contour and contour+ridge-tie, N7,964.65 and $\mathbf{N 2 8 , 4 4 6 . 0 0 / h a}$ for planting on flat and farmers practice respectively. The costs and returns analysis indicated that cultivation of rice through contour and contour plus tie ridging was more profitable than planting on flat. This implies that intensification and expansion of rice production through contour farming would increase rice productivity, increase income of farmers and optimize soil quality for sustainable productivity. In terms of gross margin per Naira invested, for every one Naira invested on rice production using contour and contour plus tie ridging and planting on flat land, a net gain of 49 and 5 kobo were obtained, while for farmer ridging practice a net loss of 18 kobo $(-0.18)$ was incurred. It would however be borne in mind however that contours are fixed assets that would have their returns/depreciation costs on construction spread over several years.

Farmers' Crop Performance Assessment: Table 5 shows farmers' ranking of their grain yields at a farmer participatory action learning research (PLAR) session conducted in the villages. Farmers ranked contour+ridge-tied treatment best performing treatment because it resulted in higher grain yield considering all four farmers' grain yields. Contoured ridges was assessed second best treatment for its better grain yields than their practice of either updown slope ridging or planting on the flat harrowed fields. 
Table 6: Costs and returns analysis contour farming practices in dandume local government area of Katsina state, Nigeria

\begin{tabular}{|c|c|c|c|c|c|c|c|c|}
\hline \multicolumn{9}{|c|}{ LOCATION : ALBASUR } \\
\hline \multicolumn{9}{|c|}{ TREATMENT } \\
\hline Costs/Returns Items & Contour & $\%$ & $\begin{array}{l}\text { Contour + } \\
\text { ridge tie }\end{array}$ & $\%$ & $\begin{array}{l}\text { Plant on Flat } \\
\text { Land }\end{array}$ & $\%$ & $\begin{array}{l}\text { Farmer } \\
\text { Practice }\end{array}$ & $\%$ \\
\hline \multicolumn{9}{|l|}{ (1) COSTS/Ha } \\
\hline Seed & $10,400.00$ & 6.38 & $10,400.00$ & 6.38 & $10,400.00$ & 6.67 & $10,400.00$ & 6.72 \\
\hline Fertilizer & $25,600.00$ & 15.72 & $25,600.00$ & 15.72 & $25,600.00$ & 16.43 & $25,600.00$ & 16.55 \\
\hline Fungicide & $1,250.00$ & 0.77 & $1,250.00$ & 0.77 & $1,250.00$ & 0.80 & $1,250.00$ & 0.81 \\
\hline Bag (Sacks) & $2,100.00$ & 1,29 & $2,100.00$ & 1,29 & $1,440.00$ & 0.92 & $1,140.00$ & 0.74 \\
\hline \multicolumn{9}{|l|}{ Labour } \\
\hline Land Preparation & $35,888.67$ & 22.03 & $35,888.67$ & 22.03 & $35,888.67$ & 23.03 & $35,888.67$ & 23.20 \\
\hline Planting & $11,718.75$ & 7.19 & $11,718.75$ & 7.19 & $11,718.75$ & 7.52 & $18,7500^{\prime} 00$ & 7.57 \\
\hline Fertilizer Application & $14,648.44$ & 8.99 & $14,648.44$ & 8.99 & $14,648.44$ & 9.40 & $14,648.44$ & 9.47 \\
\hline Weeding & $30,517.58$ & 18,74 & $30,517.58$ & 18,74 & $30,517.58$ & 19.58 & $30,517.58$ & 19.72 \\
\hline Harvesting & $12,695.31$ & 7.79 & $12,695.31$ & 7.79 & $12,695.31$ & 8.47 & $12,695.31$ & 8.21 \\
\hline Threshing & $15,637.50$ & 9.60 & $15,637.50$ & 9.60 & $10,530.00$ & 6.76 & $8,572.50$ & 5.54 \\
\hline Transportation & $2,432.50$ & 1.49 & $2,432.50$ & 1.49 & $1,146.60$ & 0.74 & $1,333.50$ & 0.86 \\
\hline $\begin{array}{l}\text { Total Variable Cost } \\
\text { (TVC)(N) }\end{array}$ & N162,888.75 & & N162,888.75 & & N155,835.35 & & N161,796.00 & \\
\hline \multicolumn{9}{|l|}{ (2) RETURNS } \\
\hline Average yield (kg/ha) & 3475 & & 3475 & & 2340 & & 1905 & \\
\hline Average Price $(\mathrm{kg} / \mathrm{ha})$ & 70.00 & & 70.00 & & 70.00 & & 70.00 & \\
\hline Gross Revenue (N/ha) & $243,250.00$ & & $243,250.00$ & & $163,800.00$ & & $133,350.00$ & \\
\hline $\begin{array}{l}\text { Gross Margin (GR - } \\
\text { TVC)(A) /ha }\end{array}$ & $80,361.25$ & & $80,316.25$ & & $7,964.65$ & & - 28,446.00 & \\
\hline Return/Naira Invested & 0.49 & & 0.49 & & 0.05 & & -0.18 & \\
\hline
\end{tabular}

either on the flats or on ridges made along the up-

Table 5: Farmer Pair-wise Ranking of Treatments performance on Rice Grain Yield

\begin{tabular}{|l|l|l|l|l|l|}
\hline Farmers & \multicolumn{3}{|l|}{$\begin{array}{l}\text { Grain Yield with Treatments } \\
\text { (kg/plot) }\end{array}$} & $\begin{array}{l}\text { Rem- } \\
\text { arks }\end{array}$ \\
\hline & C & C+RT & F & UP-S & \\
\hline $\begin{array}{l}\text { Alh. } \\
\text { MaiGari }\end{array}$ & 22.5 & 22.1 & 20.0 & 24 & 88.6 \\
\hline $\begin{array}{l}\text { Alh } \\
\text { Garba }\end{array}$ & 27.1 & 25 & 22.5 & 22 & 96.6 \\
\hline $\begin{array}{l}\text { Alh. } \\
\text { Lawal }\end{array}$ & 35.7 & 39.5 & 26.8 & 42.8 & 144.8 \\
\hline $\begin{array}{l}\text { Alh. } \\
\text { Muktari }\end{array}$ & 41.3 & 45.8 & 26.8 & 27.0 & 140.9 \\
\hline Total & 126.6 & 132.4 & 96.1 & 115.8 & \\
\hline Ranking & $2^{\text {nd }}$ & $1^{\text {st }}$ & $4^{\text {th }}$ & $3^{\text {rd }}$ & \\
\hline
\end{tabular}

Farmers found the pair-wise ranking useful because they could appreciate why over the years they had not attained yields as high as they did obtain under contoured and contoured +cross banded ridge treatments. Farmers commented that their planting of upland rice (NERICA variety) on the flat and or on the up-down slope ridges contributed to reduce their crop yields and caused erosion on their farms. In the study villages, farmers commonly plant upland rice down directions.

\section{CONCLUSION:}

In realization of the crop performance on the farmers' fields for the two years of the study, the following are inferred.

Contoured+Cross banded ridges would support optimal upland rice grain production on a sustainable base in the Nigerian Guinea Savanna. Bulk density of soils under this treatment could decrease to be lower than that on flat planted fields especially because organic matter content of the soils could decrease soil hardening. Rice stover should therefore be incorporated into the soils improve the soil quality to support sustainable agricultural production.

Planting on the up-down slope or on the flats should be discontinued among farmers and in their place, contoured and contoured+cross-banded ridging should be adopted. These would ensure soil restoration/maintenance and sustainable productivity of the soils to aid alleviation of farmer poverty conditions with increased rice yield and improved environment. 
Contoured +Cross banded ridges and Contoured ridges would also retain rain water against dry spells, check surface wash and runoff, enhance optimal rice grain yield on a sustainable basis, increase farmer income from rice production and conserve the environment against degradation.

From the above therefore, it is recommended that contoured+cross banded ridge practice be adopted as this practice would enhance rice grain yield, decrease soil crusting/hardening, mitigate soil moisture stress, control soil erosion on farmlands, ensure sustainable productivity of the soil and improve farmer livelihoods.

\section{ACKNOWLEDGEMENT:}

The authors are immensely grateful to the International Fertilizer Development Center (IFDC)Africa Lome, FARA and the Institute for Agricultural Research (IAR), Ahmadu Bello University Zaria, Nigeria for their supports for the conduct of the study and this publication.

\section{REFERENCES}

Dim, L A., A. C. Odunze, L. K. Heng and S Ajuji. 2008. Plant-Water Demand Characteristics in the Alfisol, Zaria Nigeria. In CD Proceedings of $15^{\text {th }}$ International Congress of the International Soil Conservation Organization Conference Budapest, Hungary, $18^{\text {th }}-$ $23^{\text {rd }}$ May 2008

Esu, I. E and Ojanuga, A. G. 1985. Morphological, Physical and Chemical Characteristics of Alfisols in the Kaduna Area of Nigeeria. Samaru J.Agric. Research 3(1\&2):39-49

Ike, I. F. 1987. An Evaluation of Soil Compaction and Soil Crusting Strength under different Tillage Practices in Sandy Loam Soils. $18^{\text {th }}$ Annual Conference of Soil Science Society of Nigeria (SSSN), Kaduna, 20-24 Sept. 1987. P 16

Ike, I. F. 1986. Straw-Mulch Rate Effects on Soil Moisture Content and Sorghum and Cotton Yields in a Savanna
Soil. 22 $2^{\text {nd }}$ Annual Conference of the Agricultural Society of Nigeria. Ahmadu Bello University, Zaria. $1^{\text {st }}$ $-3^{\text {rd }}$ Sept. 1986

Jones, M. J. and Wild, W. 1975. Soils of the West African Savanna. Technical Communications. No. 55. Commonwealth Bureau of Soils. CAB Harpenden. P 240

Kowal, J. M. and Knabe, D. T. 1972. An Agroclimatological Atlas of the Northern States of Nigeria. Ahmadu Bello University, Zaria Nigeria. P 111

Lombin, G. 1987. Soil and Climate Constraints to Crop Production in the Nigerian Savanna Region. $15^{\text {th }}$ Annual Conference of Soil Science Society of Nigeria (SSSN), Kaduna, 20-24 ${ }^{\text {th }}$ Sept. 1987

Odunze, A.C., G. Tarawali, and S.O. Magaji (1996). Nigerian sub-humid Savanna Zone Alfisols for Sustainable Crop and Livestock Production. Arid Soil Research and Rehabilitation Journal Vol. 1(3). 265276

Odunze, A. C. 2002. Mulching Practice for Soil Erosion Control and Grain Yield of Maize; Journal of Sustainable Agriculture, Vol. 20 (2): 31-40. The Haworth Press, Inc., New York USA

Odunze.A.C. 2003. Northern Guinea Savanna Soils and Rainfall Properties for Erosion Control and Fertility Improvement. Journal of African soils/sols Africans. African Union (AU). Scientific Technical and Research Commission, Lagos, Vol. 33:73-82.

Odunze, A. C. 2006. Soil properties and Management Strategies for some sub humid Savanna zone Alfisols in Kaduna State, Nigeria. Samaru Journal of Agricultural Research Vol. 22: 3-14

Odunze, A. C., L.A. Dim, and L K Heng. 2008. Water Supply and Rain-fed Maize Production in a Semi-Arid Zone Alfisol of Nigeria. In CD Proceedings of $15^{\text {th }}$ International Congress of the International Soil Conservation Organization Conference Budapest, Hungary, $18^{\text {th }}-23^{\text {rd }}$ May 2008. 